\title{
Status of Marco Polo sheep Ovis ammon polif in China and adjacent countries: conservation of a Vulnerable subspecies
}

\author{
George B. Schaller and Aili Kang
}

\begin{abstract}
To determine the status and distribution of the Vulnerable Marco Polo sheep or argali Ovis ammon polii surveys were made in the Pamir Mountains, where the Hindu Kush, Karakoram, and Kunlun ranges meet. In China a total of 851 Marco Polo sheep were observed within the Taxkorgan Nature Reserve and 1,448 north of the Reserve. No reliable population estimate is available for Tajikistan but in five census blocks totalling $1,977 \mathrm{~km}^{2}$ densities ranged from negligible to $1.4 \mathrm{~km}^{-2}$. A total of 624 sheep were counted in Afghanistan, and total numbers may approach 1,000. Fewer than 150
\end{abstract}

individuals are said to visit Pakistan seasonally. Hunting for meat has decimated the Marco Polo sheep populations in all four countries but with better protection they appear to be on the increase in China. Transboundary cooperation is essential if the species is to be adequately protected and managed as argali readily cross international borders, and a four-country Pamir Peace Park has been proposed and is under discussion.

Keywords Argali, China, Marco Polo sheep, Ovis ammon polii, Pamir Mountains, transboundary reserve.

\section{Introduction}

'There are great quantities of wild sheep of huge size. Their horns grow to as much as six palms in length.' Marco Polo, 1273

The Pamir Mountains with their wide valleys and rugged ranges at elevations of 3,500-5,200 $\mathrm{m}$ and above lie principally in Tajikistan but also extend into China, Afghanistan, Pakistan and Kyrgystan. The symbol of these uplands is the Marco Polo sheep Ovis ammon polii, a subspecies of argali whose long, winding horns first intrigued Marco Polo and in the 1800s became a coveted trophy of foreign hunters, a status the animal still retains today. The subspecies is categorized as Vulnerable on the IUCN Red List (IUCN, 2007). After visiting Marco Polo sheep habitat in Pakistan in 1974 and China in 1986, Schaller (1977) and Schaller et al. (1987) noted that the species' numbers had decreased greatly because of uncontrolled hunting. According to informants the sheep were suffering a similar fate in neighbouring countries but the political situations made field work difficult there during this time. Later, GBS conducted surveys in Tajikistan during June-July 2003 and February-March 2005, and in Afghanistan during August-October 2004.

George B. Schaller (Corresponding author) Wildlife Conservation Society, Bronx Park, New York 10460, USA. E-mail gbs.kms@worldnet.att.net

Aili Kang Wildlife Conservation Society-China Program, Department of Biology, East China Normal University, 3663 Zhongshan Rd. N., Shanghai 200062, China

Received 15 October 2006. Revision requested 17 November 2006 Accepted 3 February 2007
Here we summarize these findings and in particular describe our renewed research in China during OctoberNovember 2005 and May 2006. We have not been to Kyrgystan but Fedosenko (2000) provides information. A brief discussion of the status of $O$. a. polii in countries adjoining China is relevant because animals move back and forth across international borders, and conservation can be achieved only if the region as a whole is considered.

\section{Study area}

The Pamirs extend $<50 \mathrm{~km}$ into the south-west corner of the Xinjiang Uygur Autonomous Region of China where the Hindu Kush, Karakoram, and Kunlun ranges meet. Unlike the ibex Capra ibex sibirica that favours terrain on or near cliffs, Marco Polo sheep prefer rolling hills, broad valleys, and gradual mountain sides, a limited habitat in this part of Xinjiang. The Karakoram highway runs south from the city of Kashi (Kashgar) up the Taxkorgan (Taghdumbash) Valley through the middle of O. a. polii terrain, past the peak Mustag Ata $(7,546 \mathrm{~m})$ and over the Khunjerab Pass $(4,650 \mathrm{~m})$ into Pakistan. The southern part of this route lies in the Taxkorgan Nature Reserve $\left(15,863 \mathrm{~km}^{2}\right)$. The Taxkorgan Valley is so heavily settled by Tajik and Kirghiz pastoralists and agriculturalists that there are few places left where Marco Polo sheep can easily cross the valley. Suitable O. a. polii habitat extends along the China-Tajikistan border and north along the China-Kyrgystan border but our survey stopped where the three countries meet at c. $39^{\circ} 30^{\prime} \mathrm{N}$, in part because the Pamirs, as defined 


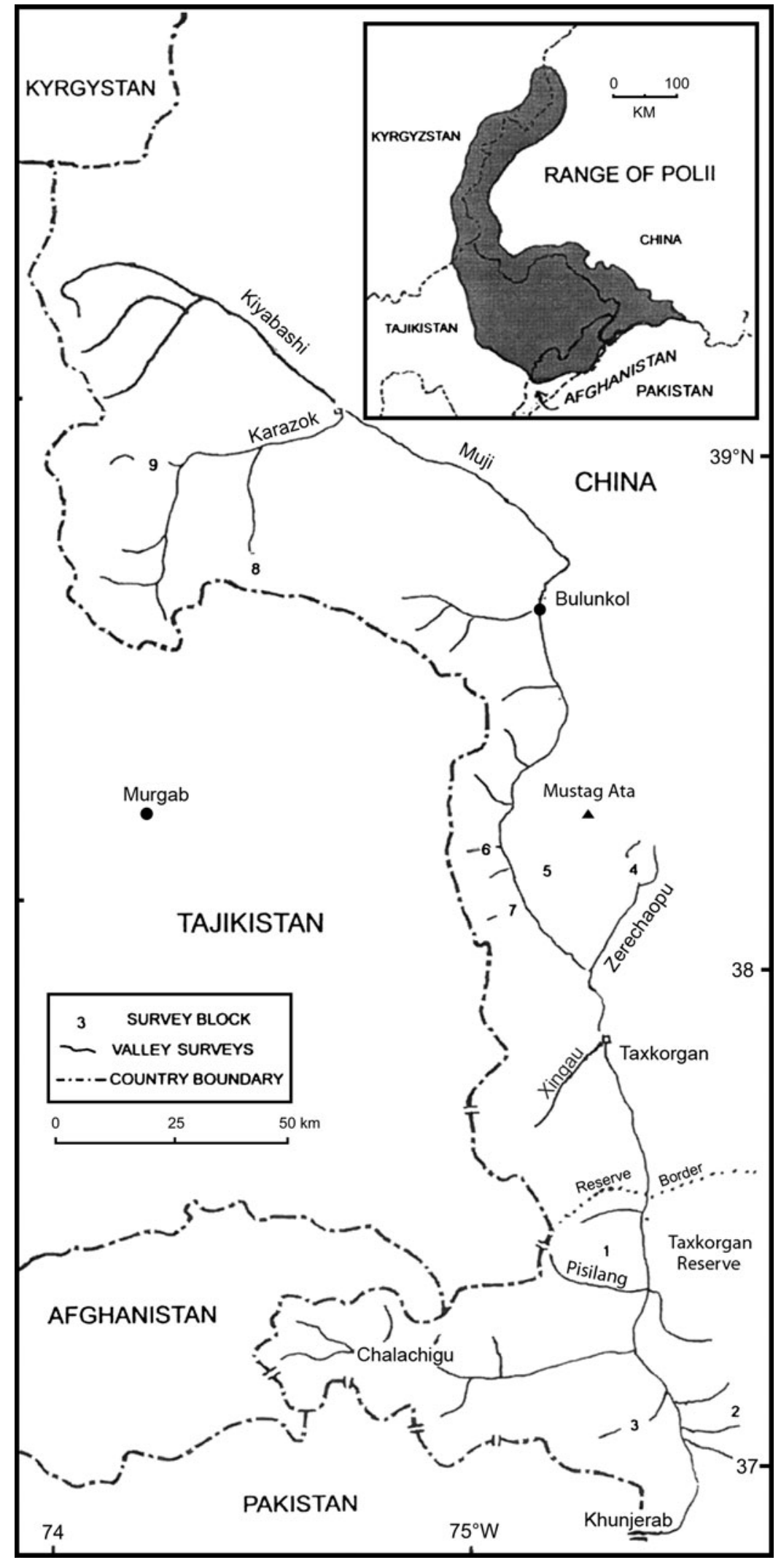

Fig. 1 The study area in the Pamir Mountains of south-west Xinjiang, China, showing the locations of the nine numbered census blocks (Table 1) and all survey routes (black lines). The shaded area in the inset indicates the range of Ovis ammon polii, which includes Kyrgystan, Tajikistan, Afghanistan and Pakistan. 
geographically, cease there and the taxonomy of argali subspecies to the north remains unclear (Fig. 1).

The main vegetation is typical of arid steppe with a ground cover of $\leq 20 \%$ consisting mainly of dwarf shrubs (Artemisia, Ceratoides) and graminoids, particularly the grass Stipa. The region is treeless except around irrigation that ceases at c. 3,500 m. Willow (Salix) and buckthorn (Hippophae) occur naturally along some streams. Along water courses, rivulets and seepages the sedge Kobresia may grow in a solid mat, and forbs such as Primula, Iris and Gentiana add variety and colour in season.

\section{Methods}

In China, after obtaining information about the general distribution of Marco Polo sheep from local people and the Forestry Department, two sampling strategies were used to census animals. A block of suitable O. a. polii terrain was selected and all animals tallied within it by walking or riding along valleys and ridges and across plateaus while scanning slopes with binoculars and spotting scopes. This provided a minimum count. Nine census blocks totalling $865 \mathrm{~km}^{2}$ were covered (Table 1). In addition, most valleys with $O$. a. polii habitat were investigated and systematic counts made along the bordering slopes; all surveyed valleys are shown in Fig. 1. Certain areas had concentrations of animals and others few or none. The results for a particular site are only indicative for the time of our survey because animals may shift activities seasonally, move away when herders with livestock move in, and travel across international borders. The sheep are shy, sometimes fleeing on perceiving us at a distance of $500 \mathrm{~m}$ or more, often making it difficult to do more than count them. When possible, all animals in a small herd or subgroup of a large herd were classified as young, female (yearling and adult), yearling male (1-2 years old), small-horned male (2-3 years), medium male (3-5 years), and large male ( 5 years and older).

Marco Polo sheep in Tajikistan were counted in 2003 in five census blocks totalling $1,977 \mathrm{~km}^{2}$, all selected in areas said to have many animals, from Lake Karakul in the north to the Afghan border in the south. The survey in the road-less Afghan Pamirs in 2004 involved walking up most major valleys, a total of 13 that, according to local informants, contained $O$. a. polii at that season. Work had to be terminated when close to completion in the Big Pamir Reserve because of heavy October snows.

\section{Results}

\section{Distribution and status in China}

China's Taxkorgan Reserve extends from c. 3730' N south to the Pakistan border. We censused three blocks
Table 1 Number of Marco Polo sheep in census blocks in China (data collected October-November 2005).

\begin{tabular}{lrrl}
\hline Census block & $\begin{array}{l}\text { Area } \\
\left(\mathrm{km}^{2}\right)\end{array}$ & No. & $\begin{array}{l}\text { Density } \\
\left(\mathrm{km}^{-2}\right)\end{array}$ \\
\hline 1, Pisilang (Taxkorgan Reserve) & 150 & 436 & 2.9 \\
2, Sankan (Taxkorgan Reserve) & 170 & 7 & 0.04 \\
3, Patipak (Taxkorgan Reserve) & 150 & 0 & 0 \\
4, Zerechaopu & 60 & 73 & 1.2 \\
5, Mustag & 70 & 0 & 0 \\
6, Kolassu & 100 & 64 & 0.6 \\
7, Kyindi & 40 & 0 & 0 \\
8, llbal & 55 & 201 & 3.7 \\
9, Keyigenitek & 70 & 290 & 4.1 \\
\hline
\end{tabular}

*Census block numbers correspond to those in Fig. 1; census block name is usually that of a prominent valley.

totalling $470 \mathrm{~km}^{2}$ as well as most valleys within the Reserve (Fig. 1, Table 1). Few animals were in the hills east of the Taxkorgan Valley. In the Chalachigu Valley, which projects west to Afghanistan, 284 O. a. polii were tallied, considerably more than the 89 seen during a less intensive survey in 1986 (Schaller et al., 1987). The Pisilang census block on the west side of the Taxkorgan Valley had the largest $O$. a. polii concentration in the Reserve, with 436 individuals, and an additional 100 or more were just to the north. Thus c. 851 O. a. polii were observed within the Reserve, and the total may be c. 1,100 .

The mountains bordering the Taxkorgan Valley from the Reserve border north to the Mustag Ata massif provide only patchy argali habitat but there is much suitable terrain around the base of the peak. In four census blocks totalling $270 \mathrm{~km}^{2}$ we counted 137 O. a. polii, and in two valleys projecting towards Tajikistan an additional 341. The high Kongur Range blocks Marco Polo sheep to the north and north-west of the county town of Bulunkol. However, the species occurs west of Bulunkol up the Muji River and its two major tributaries, the Karazok and Kiyakbashi. We counted 846 O. a. polii in the Muji drainage system, excluding the Kiyakbashi, in 2005. AK returned in 2006 to census the Kiyakbashi and added 124 more to the total. We thus observed 2,299 Marco Polo sheep in the Chinese Pamirs within our survey area.

Because O. a. polii may cross international borders the status of the species in China is to some extent dependent on the conservation situation in neighbouring countries. In the south, particularly the Taxkorgan Reserve, rugged mountains limit O. a. polii movement between countries to a few passes. The Wakhjir Pass at the western tip of the Chalachigu Valley provides the only route to and from Afghanistan. Five known passes enable the sheep to enter Pakistan from China, but at three of these (Kilik, Mintaka, Karchanai) they are 
confined to only a little habitat near the border. The Khunjerab Pass leads to over $50 \mathrm{~km}^{2}$ of good habitat but the Karakoram highway, with all its traffic leading up the narrow valley to the pass, as well as a border fence partially across the valley at the Pakistan border, have greatly reduced O. a. polii movement. Farther east the animals are said to travel up the Uplang Valley, a tributary to the Khunjerab, over the Tikalik Pass, and into a broad valley whose southern slopes are on the Pakistan side of the border. Only two passes provide access from China into the south-east corner of Tajikistan, according to local informants (Fig. 1). But north of c. $38^{\circ} \mathrm{N}$ the precipitous terrain is often replaced by high rolling hills or broad passes that provide travel routes between China and Tajikistan except for short fences at border posts and at certain places to keep yaks from straying.

\section{Distribution and status in adjacent countries}

Tajikistan Marco Polo sheep in Tajikistan occur mainly in the eastern half of the Pamirs, east of $72^{\circ} 30^{\prime}$ E. It is generally agreed that there has been a great decline since the 1960s. Current estimates range from 3,000-5,400 (Anon., 2003) to 13,000-14,000 (Fedosenko, 2003). We cannot provide a reliable estimate of total number because our surveys were confined to certain sites. However, we think Fedosenko's (2003) figure is of the correct order of magnitude. In the five census blocks we counted a total of 1,528 animals, or $0.8 \mathrm{~km}^{-2}$, in 2003 . Densities varied from one block with negligible numbers and three blocks with $0.3-0.5 \mathrm{~km}^{-2}$ to one large block $\left(800 \mathrm{~km}^{2}\right)$ within a hunting concession with $1.4 \mathrm{~km}^{-2}$. We returned to the latter block in 2005 and counted 2,200 animals or $2.7 \mathrm{~km}^{-2}$, the increase possibly because of a winter concentration. Animals can move between Tajikistan and Afghanistan without difficulty, especially in the western part where the border follows the Pamir River and in the south-eastern part where only low hills separate the countries. Russia built an 18strand barbed-wire fence $>2 \mathrm{~m}$ high near the China border 10-30 km within Tajikistan. This fence, $350 \mathrm{~km}$ long, limits O. a. polii to a narrow strip of land if they enter the country from China, except for $c .50 \mathrm{~km}$ in the most southern part where local people have cut the fence posts for fuelwood.

Afghanistan During the survey in the Afghan Pamirs we counted 624 O. a. polii but we had only a cursory look at one important area, the Big Pamir Reserve. Perhaps 1,000 animals frequent the country. There has been a decline both in number and distribution: Petocz et al. (1978) counted 1,260 and estimated 2,500 during the 1970s.

Pakistan O. a. polii in Pakistan once occurred in their hundreds; in 1959 an American hunter saw a herd of
65 males (Clark, 1964). During the construction of the Karakoram highway in the late 1960s and early 1970s argali were shot for food and numbers declined drastically. Rasool (1989) censused animals around the Khunjerab Pass, counting 300 in 1974, 100 in 1980, and 20 in 1988. Tourists told us of seeing 12-14 in November 2005. At the head of the Kharchanai Valley 52 were counted in 1989 (Ahmad, 1996) and 45 in 1991 (Khan, 1991). GBS saw O. a. polii skulls at Kilik Pass in 1974 but no recent information is available. The total Marco Polo population probably does not exceed 150, most or all animals being seasonal visitors from China.

Kyrgystan Mountains stretch north along the ChinaKyrgystan border without major interruption to the Tian Shan, a major range that extends east-west. Argali distribution is continuous between the Pamirs and Tian Shan. Only minor differences in the pattern of pelage colouration and possibly horn conformation exist in the animals of the two mountain systems (Geist, 1991). There is disagreement whether all animals are O. a. polii or whether those in the Tian Shan represent a distinct subspecies, O. a. karelini (Shackleton, 1997; Fedosenko, 2003). Clark (1964) listed yet a third subspecies, O. a. humei, in the area that connects the two major ranges. By contrast, Fedosenko \& Weinberg (1999) stated that O. a. polii occurs north only to $c .40^{\circ} 50^{\prime} \mathrm{N}$ (Fig. 1) and there gives way to O. a. karelini. Argali along the China-Kyrgystan border obviously require taxonomic research. Fedosenko (2003) estimated that 6,000-7,000 O. a. polii occurred in south-eastern Kyrgystan near the China border in the late 1990s. Density was c. $2.3 \mathrm{~km}^{-2}$ within one area of 2,000 $\mathrm{km}^{2}$ (Fedosenko \& Weinberg, 1999). No similar figures are available from the Chinese side of the border. AK confirmed that argali distribution continues northward in China along the Kyrgystan border by visiting three sites as far north as $40^{\circ} 28^{\prime} \mathrm{N}$ and observing 94 argali.

\section{Population composition}

The sexes are largely segregated for most of the year with males in separate herds that are often in different valleys and at a higher elevation than females and young. To obtain an accurate ratio of males to females is difficult except during the winter rut. Therefore, our data and those of other investigations (Petocz et al., 1978; Fedosenko, 2000) make comparisons unreliable unless collected at the same time of year. The rut had not begun by mid November 2005 during our China survey. At that time our sample gave a male:female ratio of only 22:100 with proportionately more males in the southern part of the study area $(35: 100, \mathrm{n}=725)$ than the northern one $(12: 100, n=866)$. The low number of males presumably indicated that many had moved elsewhere, such as into Tajikistan. By contrast, the ratio 
was $56: 100(\mathrm{n}=1,055)$ in Tajikistan during the summer of 2003.

The ratio of young to females (adult and yearling) in China was $40: 100(n=1,816)$, a figure comparable to the 48:100 ( $\mathrm{n}=1,001$ ) calculated by us for Tajikistan in 2003 and the 46:100 reported by Fedosenko (2000) for the same country. Judging by these ratios and the fact that yearlings do not give birth, reproductive success was adequate.

Mean size of 43 male herds in China was 7.8 \pm SD 9.0 (range 1-42), similar to the mean of $9.0 \pm$ SD 11.0 (range 2-44) we recorded in 22 herds in Afghanistan, and mean of $9.4 \pm$ SD 8.0 (range 1-33) in 18 herds in Tajikistan if two large herds of 81 and 110 are excluded from the computations. Male herds tended to segregate into age groups with, for example, only young males aged 3 years or less together or only large-horned males. An examination of horns found indicated that males seldom reached an age of 10-11 years. Excluding the small horns of yearlings, $68 \%(n=53)$ had died at $4-7$ years of age in Tajikistan and $71 \%(\mathrm{n}=42)$ in Afghanistan. We seldom noted horns during our 2005 survey in China, probably because people collect them, but 55\% ( $n=130)$ had died in that age group in our 1986 sample (Schaller et al., 1987). Hunting for meat by local people and to much lesser extent predation by wolves Canis lupus caused most deaths.

Eighty-two female herds, including a variable number of females, yearlings, and young, had a mean size of $19.1 \pm$ SD 21.2 (range 2-137) in our 2005 China survey. Large female herds were also observed in Tajikistan with the two largest consisting of 138 and 183 individuals. In early spring when many males, particularly young ones, have not yet separated from the females, the mixed herds may be even larger. Our highest counts in Tajikistan numbered 148, 153, 315 and 490.

\section{Discussion}

All countries except Pakistan retain moderately large Marco Polo sheep populations, making it possible to manage them effectively on a long-term basis. However, only in China has O. a. polii apparently increased during the past 2 decades, largely because of a guard force and confiscation of firearms from households. Some areas of suitable habitat in China still support few animals, but whether this reflects poor pasture conditions, excessive human disturbance, or terrain into which animals are just beginning to expand is unclear. All pastures are used seasonally by livestock, some heavily. Marco Polo sheep forage on a large variety of graminoids, forbs and dwarf shrubs (Fedosenko, 2000), as do livestock, making competition for a limited resource inevitable. Local informants told us, and we verified it, that when livestock move into a valley the $O$. $a$. polii tend to move out but this may in part be a response to the presence of people. Growing human and livestock populations will place ever more pressure on rangelands, and conflict over forage between wild and domestic ungulates will increase. The effects of pasture degradation by livestock on wild ungulates have been well documented in the Indian Himalaya (Bagchi et al., 2004; Mishra et al., 2004; Namgail et al., 2008).

There is little precise information available about Marco Polo sheep numbers, population dynamics, movement patterns, and other aspects of behaviour, and the same is true for other large mammals in the Pamirs, among them ibex, snow leopard Panthera uncia, brown bear Ursus arctos and wolf. Systematic recording and monitoring is essential for good management, tasks for which local guards and others need to be trained (something that the Wildlife Conservation Society is now doing in China and Afghanistan). Such monitoring would also alert officials to such problems as the recent outbreak of what appears to be sarcoptic mange in ibex and blue sheep Pseudois nayaur in the Taxkorgan Reserve.

Trophy hunting of Marco Polo sheep in China in recent times began in 1980 when a US citizen shot three males in the Chalachigu Valley (local officials, pers. comm.). The occasional animal has been shot in the Taxkorgan Reserve since then but the reserve is now closed to this activity. Other areas remain open to trophy hunting. Counts should be made to determine a sustainable kill of trophy-sized males (horns at least $135 \mathrm{~cm}$ long).

Some environmental issues also affect neighbouring countries. In Pakistan the rangelands of Marco Polo sheep are in conflict with demands of livestock herders (Ahmad, 1996). Kirghiz occupy the eastern part of the Afghan Pamirs and Wakhi the western part. The rangelands of the former remain in relatively good condition in part because many households emigrated with their livestock in 1978, whereas in the latter the pastures are seriously degraded. Community problems among the 250 or so Kirghiz households include opium use, illiteracy, and lack of access to schools and medical services. The Big Pamir Wildlife Reserve $\left(679 \mathrm{~km}^{2}\right)$ was designated in the 1970s but not legally established. The reserve was used by trophy hunters between 1966 and 1977 (Petocz et al., 1978). All hunting is currently banned in Afghanistan but distant edicts have little local influence.

Most herders in Tajikistan move to community centres for the winter, leaving large areas of rangeland unoccupied. Social services collapsed after the Russian withdrawal in 1991. Livestock numbers have decreased as households have had to sell animals to buy food; 12 
of 24 households interviewed by us said that they did not get enough to eat. Consequently, pastures in many areas are in fair to good condition. Uncontrolled and unsustainable hunting by local people, border guards and others is widespread. About 40-60 permits to kill Marco Polo sheep are officially given to foreigners each year for a price of USD 22,000 or more, money that could benefit conservation and local communities. Two reserves contain Marco Polo sheep, the Zorkul Strictly Protected Area $\left(870 \mathrm{~km}^{2}\right)$ and the Pamir National Park $\left(26,000 \mathrm{~km}^{2}\right)$, but neither has adequate protection. There are eight trophy hunting concessions of which only the Murgab Company seems to protect its area well. It is not coincidental that O. a. polii density is greater there than elsewhere in Tajikistan.

When Marco Polo sheep move across frontiers the animals encounter various problems ranging from an impenetrable fence in Tajikistan to heavy hunting by local people, and it is clear that any one country cannot adequately protect and manage the species. Only through transboundary cooperation and joint conservation initiatives is this possible on a sustained basis. Schaller et al. (1987) urged the creation of one large reserve that encompasses the Pamir border areas of Pakistan, Tajikistan, Afghanistan and China, establishing in effect a large Pamir International Peace Park. Different levels of protection would apply to such a transboundary reserve depending on ecological, cultural and political considerations. Each country would decide which type of land use is most effective and appropriate. The reserve could include protected areas in which certain forms of human activity are curtailed, hunting concessions that help raise funds for conservation and local communities, restricted military border zones, and managed rangelands on which households maintain traditional livelihoods. The total area of the proposed Peace Park would be at least $40,000 \mathrm{~km}^{2}$, or $50,000 \mathrm{~km}^{2}$ if Pakistan adds the Central Karakoram National Park $\left(9,738 \mathrm{~km}^{2}\right)$, adjoining the Khunjerab National Park to the east, even though it lacks Marco Polo sheep. A Peace Park would enable the countries to manage joint resources better, share scientific and other information for mutual benefit, and encourage neighbourly relations through research, training and education.

A workshop on Pamir conservation was held in Urumqi, Xinjiang, during 28-29 September 2006, sponsored by the Wildlife Conservation Society and China's State Forestry Administration. Delegations from China, Tajikistan, Afghanistan and Pakistan attended. The delegates agreed to promote the establishment of a fourcountry transboundary conservation area or Peace Park and they delineated tentative borders. More joint meetings are planned and informal discussions have been held in each country.
The Marco Polo sheep is a natural flagship species for the Pamir Mountains and as such can help all species, and the local peoples, in this unique ecosystem to survive and prosper.

\section{Acknowledgements}

The research was funded by the Wildlife Conservation Society and in Tajikistan and in Afghanistan also by the National Geographic Society. Many people assisted the project and we are especially grateful to Zhu Fude and Shi Jun of the Xinjiang Forestry Department, Urumqi, and Xie Yan of the Wildlife Conservation Society, Beijing, for promoting the work. For capable assistance in the field we wish to thank Dai Zhigang, Hu Zuojun, Hao Shulian, Xi Zhinong, Ga Wa Xia, Ren Min Li and others (China); Yakub Khan, Sarfraz Khan, Muhammad Sadiq and Beth Wald (Afghanistan); Kokul Kasirov, Abdusattor Saidov, Otabek Bekmurodi and Tolibek Gulbekov (Tajikistan).

\section{References}

Ahmad, A. (1996) Management Plan, Khunjerab National Park. WWF-Pakistan, Lahore, Pakistan.

Anon. (2003) National Strategy and Action Plan on Conservation and Sustainable Use of Biodiversity. National Biodiversity and Biosafety Center, Dushanbe, Tajikistan.

Bagchi, S., Mishra, C. \& Bhatnagar, Y. (2004) Conflicts between traditional pastoralists and conservation of Himalayan ibex (Capra sibirica) in the Trans-Himalayan mountains. Animal Conservation, 7, 121-128.

Clark, J. (1964) The Great Arc of Wild Sheep. University of Oklahoma Press, Norman, USA.

Fedosenko, A. (2000) Argali Sheep in Russia and Adjacent Territories. Centre for Hunting Control, Moscow, Russia. [in Russian]

Fedosenko, A. (2003) Status of the argali (archar) populations in Russia and Republics of Middle Asia. Beitrage zur Jagd und Wildforschung, 28, 143-149.

Fedosenko, A. \& Weinberg, P. (1999) The status of some wild sheep populations in the CIS (former USSR) and the impact of trophy hunting. Caprinae, May, 1-4.

Geist, V. (1991) On the taxonomy of giant sheep (Ovis ammon Linnaeus, 1766). Canadian Journal of Zoology, 69, 706-723.

IUCN (2007) 2007 IUCN Red List of Threatened Species. IUCN, Gland, Switzerland. Http://www.iucnredlist.org [accessed 21 November 2007].

Khan, A. (1991) Marco Polo's sheep doing well. Natura (WWF Pakistan Newsletter), 10, 31.

Mishra, C., van Wieren, S., Heitkonig, I. \& Prins, H. (2004) Competition between livestock and bharal Pseudois nayaur in the Indian Trans-Himalaya. Journal of Applied Ecology, 41, 344-354.

Namgail, T., Bagchi, S., Mishra, C. \& Bhatnagar, Y.V. (2008) Distribution correlates of the Tibetan gazelle Procapra picticaudata in Ladakh, northern India: towards a recovery programme. Oryx, 42, 107-112. 
Petocz, R., Habibi, K., Jamil, A. \& Wassey, A. (1978) Report on the Afghan Pamir. Part 2. Biology of Marco Polo Sheep (Ovis ammon polii). UNDP, FAO, Ministry of Agriculture, Kabul, Afghanistan.

Rasool, G. (1989) Wildlife in the wilderness. Natura (WWF Pakistan Newsletter), 8, 4-6.

Schaller, G. (1977) Mountain Monarchs: Wild Sheep and Goats of the Himalaya. University of Chicago Press, Chicago, USA.

Schaller, G.B., Li, H., Talipu, Lu, H., Ren, J., Qiu, M. \& Wang, H. (1987) Status of large mammals in the Taxkorgan Reserve, Xinjiang, China. Biological Conservation, 42, 53-71.

Shackleton, D. (ed.) (1997) Wild Sheep and Goats and their Relatives. IUCN/SSC Caprinae Specialist Group, Gland, Switzerland.

\section{Biographical sketches}

George B. Schaller is Vice President for Science and Exploration at the Wildlife Conservation Society. He has been active in conservation and research on carnivores and ungulates in various countries for half a century. Aili Kang coordinates research and conservation in western China for the Wildlife Conservation Society's China programme. In addition to continuing work on Marco Polo sheep, she has conducted studies of saiga and Tibetan antelope. 